\title{
Rediscovering Cycloramphus bandeirensis (Anura: Cycloramphidae): natural history and breeding biology of a vulnerable species with a variant reproductive mode
}

\author{
Vanessa Kruth Verdade, ${ }^{1}$ Diego Almeida-Silva, ${ }^{1}$ José Cassimiro, ${ }^{2}$ and Miguel Trefaut Rodrigues ${ }^{2}$ \\ ${ }^{1}$ Centro de Ciências Naturais e Humanas, Universidade Federal do ABC. Av. dos Estados, 5001, 09210-580, Santo André, SP, \\ Brazil. E-mails: vanessa.verdade@ufabc.edu.br, silva.diego.almeida@gmail.com. \\ ${ }^{2}$ Instituto de Biociências, Universidade de São Paulo. Rua do Matão, Travessa 14, 101, 05508-090, São Paulo, SP, Brazil. \\ E-mails: geckoides@gmail.com, mturodri@usp.br.
}

\begin{abstract}
Rediscovering Cycloramphus bandeirensis (Anura: Cycloramphidae): natural history and breeding biology of a vulnerable species with a variant reproductive mode. We present here data on the breeding biology of Cycloramphus bandeirensis, including descriptions of the advertisement call and tadpole. Males call from beneath rocks in open grasslands above approximately 2,450 $\mathrm{m}$ a.s.l. at the Parque Nacional do Caparaó, southeastern Brazil. Breeding occurs from late October-December, when mist and clouds frequently cover the area. The advertisement call consists of a first note, followed by two or three shorter ones. The spawn is hidden under rocks from which the males call, and the tadpoles are exotrophic and semiterrestrial. This report of a semiterrestrial tadpole that develops in seclusion in a terrestrial habitat is a variant of Reproductive Mode 19. We compared the ontogeny of the semiterrestrial tadpole of $C$. bandeirensis to that of generalized tadpoles, and a new function is ascribed to the skin flap that is present in larvae of Cycloramphus. It is suggested that $C$. bandeirensis be transferred to Vulnerable category (VU, d2) of IUCN; the species has a small geographic range $\left(<20 \mathrm{~km}^{2}\right)$, specialized environmental requirements, is vulnerable, has phylogenetic affinities to species that consistently have undergone local population crashes in southeastern Brazil, and is subject to plausible potential threats in its range (e.g., fires and climate change).
\end{abstract}

Keywords: Atlantic Forest Domain, endemic species, heterochrony, semiterrestrial tadpole, southeastern Brazil.

Received 02 August 2019

Accepted 21 November 2019

Distributed December 2019 


\begin{abstract}
Resumo
Redescoberta de Cycloramphus bandeirensis (Anura: Cycloramphidae): história natural e biologia reprodutiva de uma espécie vulnerável com modo reprodutivo diferenciado. Apresentamos aqui dados sobre a biologia reprodutiva de Cycloramphus bandeirensis, incluindo a descrição do canto de anúncio e dos girinos. Os machos vocalizam escondidos sob rochas nos campos de altitude acima de aproximadamente $2450 \mathrm{~m}$ de altitude no Parque Nacional do Caparaó, sudeste do Brasil. A reprodução ocorre do final de outubro a dezembro, quando neblina e nuvens cobrem a área frequentemente. O canto de anúncio consiste de uma primeira nota, seguida de duas a três notas mais curtas. A desova ocorre sob as rochas, de onde os machos vocalizam, e os girinos são exotróficos e semiterrestres. Este registro de girino semiterrestre, que se desenvolve abrigado em ambiente terrestre, é uma variação do Modo Reprodutivo 19. Comparamos a ontogenia dos girinos semiterrestres de $C$. bandeirensis à de girinos de morfotipos mais generalistas e sugerimos uma nova função para a dobra de pele presente nos girinos de Cycloramphus. Sugerimos transferir $C$. bandeirensis para a categoria Vulnerável (VU, d2) da IUCN; a espécie apresenta distribuição geográfica restrita $\left(<20 \mathrm{~km}^{2}\right)$, altos requerimentos ambientais, vulnerabilidade, afinidade filogenética a espécies que sofreram declínios populacionais no sudeste do Brasil e está sujeita a ameaças potenciais plausíveis na área de ocorrência (e.g., incêndios e alterações climáticas).
\end{abstract}

Palavras-chave: espécie endêmica, girino semiterrestre, heterocronia, Mata Atlântica, sudeste do Brasil.

\section{Introduction}

Cycloramphidae is endemic to Brazil; the family includes Thoropa, Cycloramphus, and Zachaenus (Frost 2019), of which the latter two are endemic to the Atlantic Forest Domain (Heyer 1983a,b, Verdade et al. 2009a). The species in the family typically are forest inhabitants that are associated with forest litter, rocky outcrops, or fast-flowing streams. The external morphology of the adults ranges from semi-fossorial to terrestrial morphotypes in which the toes lack webbing and the legs are short and robust to semi-aquatic morphotypes having toe webbing, slender bodies, and longer legs (Heyer 1983a, Verdade and Rodrigues 2003, Lima et al. 2012). There are two tadpole morphotypes in the family-exotrophic semiterrestrial tadpoles and the endotrophic terrestrial larvae (Lutz 1944, Bokermann 1965, Heyer 1983a, b, Heyer and Crombie 1979). All semi-fossorial species are associated with forest litter and have endotrophic, terrestrial tadpoles, whereas the semi-aquatic species are associated with streams and have exotrophic, semi-terrestrial tadpoles (e.g., Heyer and Crombie 1979, Heyer 1983a, b).
Cycloramphus is the most speciose genus in Cycloramphidae; it contains 28 species (Frost 2019), with representatives of both terrestrial and semi-aquatic adult and tadpole morphotypes. All species of Cycloramphus inhabit forested areas except two species-C. bandeirensis and $C$. organensis that live in the open high grasslands of the Parque Nacional do Caparaó and the Parque Nacional da Serra dos Órgãos, respectively (Heyer 1983a, Heyer and Maxson 1983, Weber et al. 2011).

Little is known about the natural history of Cycloramphus (Giaretta and Facure 2003, Hartman et al. 2003, Lingnau et al. 2008, Verdade et al. 2009b). Advertisement calls are known for 13 species and there are descriptions of tadpoles for only nine species in the genus. The calls range from short simple metallic calls to long simple calls, and complex ones (Heyer 1983a). No correlations have been made among different habitats, adult morphotypes, or phylogeny.

The habitat and reproductive specializations in Cycloramphidae contribute to the high diversity of anuran reproductive modes (RM) in the Atlantic Forest (Haddad and Prado, 2005, 
Iskandar et al. 2014). Species of Thoropa and most species of Cycloramphus have RM 19. The females lay their eggs exposed on humid rocks, in rock crevices, or on tree roots above water; tadpoles are exotrophic and semiterrestrial, living on rock and rock crevices in a water film or in the water-land interface in the splash zones near waterfalls (Bokermann 1965, Heyer 1983a, b). All species in Zachaenus have RM 21, in which eggs hatch into endotrophic tadpoles that complete their development in concealed nests placed under leaf litter (Lutz 1944, Zocca et al. 2014, Almeida-Silva et al. 2019). Some species of Cycloramphus have RM 22, in which females lay eggs concealed on land; the female remains in the nest, which usually is placed in natural or constructed cavities. The larvae hatch into endotrophic tadpoles that climb on the female's dorsum where they complete their development (Heyer and Crombie 1979, VKV pers. obs.). Among the few anurans that have RMs 19, 21, and 22 (Haddad and Prado 2005) are Indirana (Ranixalidae) and Petropedetes (Petropedetidae) (RM 19, Ranoidea); Eupsophus (RM 21, Alsodidae, Hyloidea); Rhinoderma (RM 22, Rhinodermatidae, Hyloidea); and Leiopelma (RM 22, Leiopelmatidae, Ranoidea) (Wells 2007). Detailed anatomical and ontogenetic comparisons among larvae are lacking to test homology in the cases mentioned, and similarities observed are probably result of convergence in the evolutionary history of Anura. Likewise, the lack of natural history data and a stable phylogeny for Cycloramphidae preclude speculations as to the origin of reproductive specializations and tadpole morphotypes in this family. The monophyly of the family is debated (Frost et al. 2006, Grant et al. 2017, Jetz and Pyron 2018, Streicher et al. 2018) and the familial internal relationships are poorly resolved (Verdade 2005, Weber et al. 2011, Fouquet et al. 2013, Barros 2016, Sabbag et al. 2018, de Sá et al. 2019).

Cycloramphus bandeirensis is endemic to the open, high grasslands of Parque Nacional do
Caparaó, and was last encountered in 1981 (Heyer 1983a). Few data on the species are available; however, there are unpublished field notes of William Ronald Heyer and Paulo Emilio Vanzolini housed at the library of the Museu de Zoologia da Universidade de São Paulo (MZUSP). During a series of herpetological surveys in the Caparaó Mountains, we collected new specimens and eggs of $C$. bandeirensis, which enable us to elucidate the natural history and breeding biology of Cycloramphidae.

\section{Materials and Methods}

Fieldwork was conducted at the type locality of Cycloramphus bandeirensis in the high grasslands of Parque Nacional do Caparaó, southeastern Brazil (Figure 1; see Rodrigues et al. 2009). We sampled the area between October and January from 2004-2008 for a total of 50 days during the rainy season.

Forests and high grasslands from 800-2890 $\mathrm{m}$ were surveyed on both the west and east sides of the park. We searched for frogs by walking in streams, as well as along the margins of the streams, in grasslands by day and at night, and turned over scattered rocks in the open field. We calculated the area $\left(\mathrm{km}^{2}\right)$ of high grasslands (2000-2890 m) and the range of occurrence of $C$. bandeirensis based on elevations between 2450 and $2890 \mathrm{~m}$ in the park using topographic contour lines and calculating surface area in QGIS (2019).

We collected adults and eggs in the field

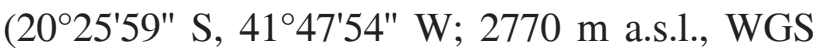
84). An egg mass was found under a rock in the open field; the eggs were placed in a plastic box and transported to the laboratory, where we divided the egg mass into two groups that were maintained in separate closed plastic boxes. One box was kept on a dark shelf at room temperature $\left(22-32^{\circ} \mathrm{C}\right)$, and the other was refrigerated at $6-10^{\circ} \mathrm{C}$. After hatchling, tadpoles were reared until metamorphosis in a terrarium; emergent rocks were placed in water in the bottom of the 
A

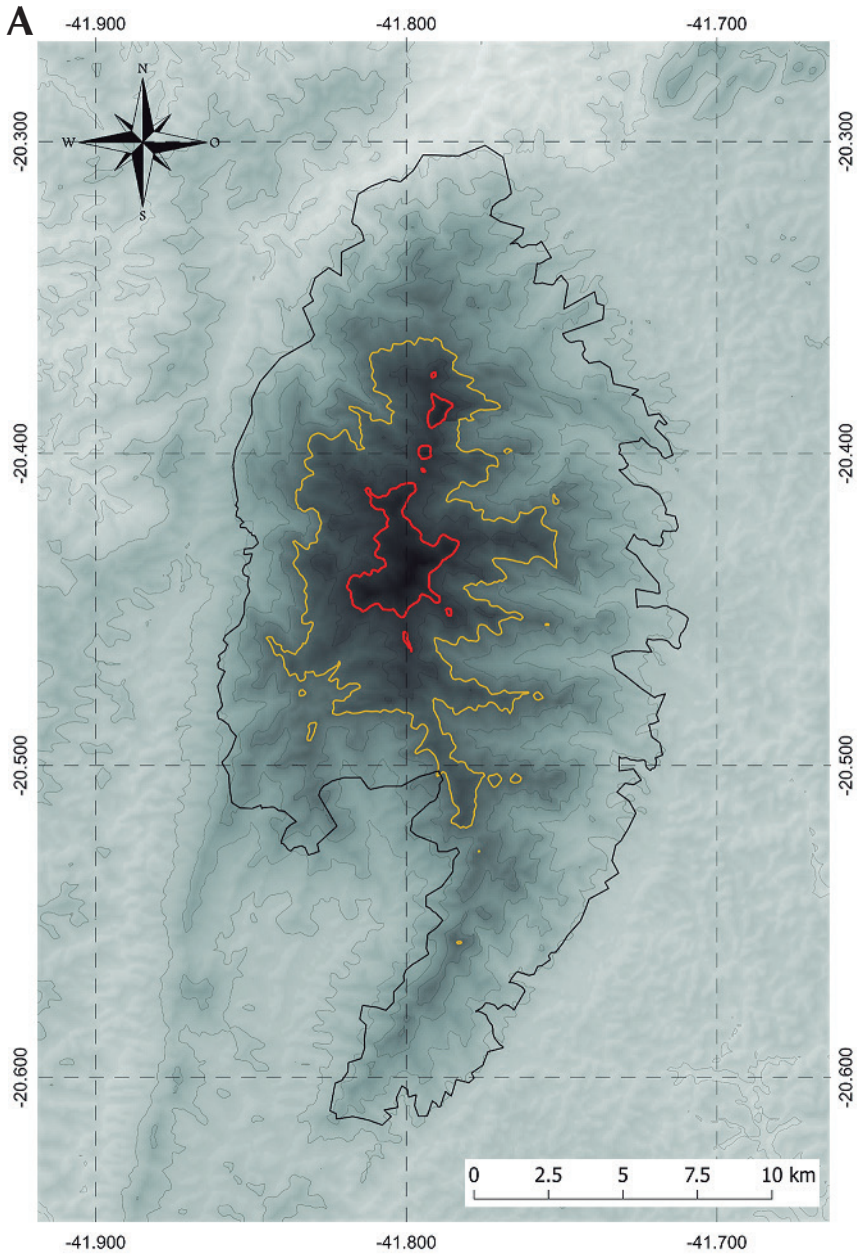

B

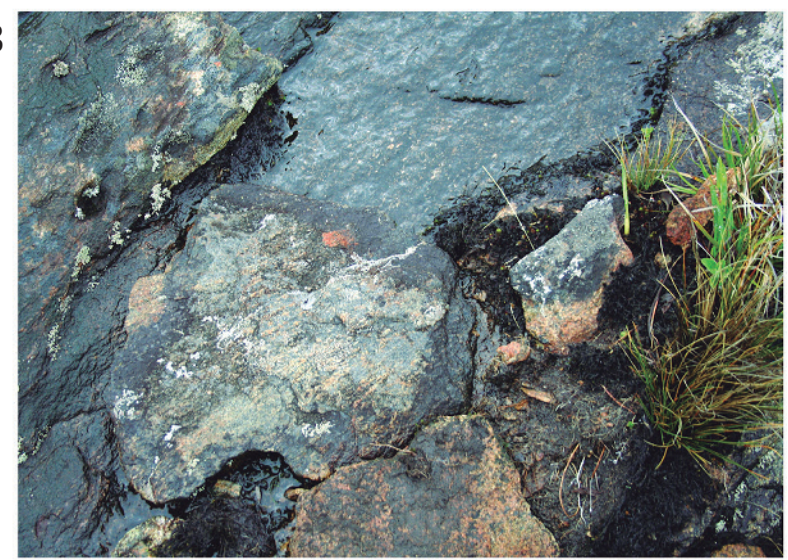

C

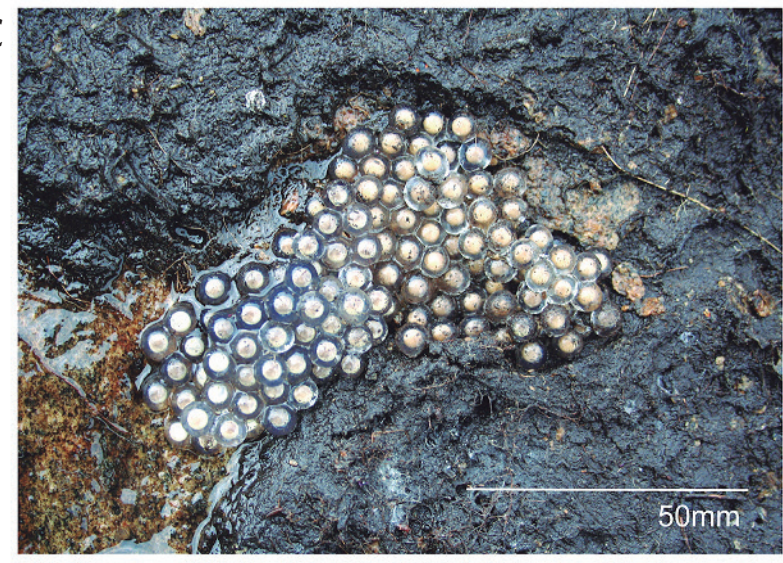

Figure 1. (A) Border of Parque Nacional do Caparaó (black line); high grasslands in the park (2000-2890 m; yellow line); IUCN website distribution (Silvano and Heyer 2004; green line); and high grasslands where specimens of Cycloramphus bandeirensis were recorded (2450-2890 m; red line). Reproductive site (B) and spawn (C) on underside of rock (Photos: J. Cassimiro). Source map modified from Ministério do Meio Ambiente (http:// www.mma.gov.br/governanca-ambiental/geoprocessamento) with QGIS (2019).

terrarium and water was pumped over the rocks. Some of the rocks provided moist surfaces where the larvae could feed and hide. The tadpoles were mainly fed banana rind, supplemented with wet rabbit pellets, lettuce, and fish food flakes. Individuals captured in the field were euthanized with an overdose of anesthetics (GBBPEA 2013), fixed in 5\% formaldehyde (eggs and tadpoles) or $10 \%$ formaldehyde (adults), and stored in formalin (eggs and tadpoles) or in ethanol 70\% (adults). We deposited voucher specimens at the Museu de Zoologia da Universidade de São Paulo (MZUSP 133852, 133898, 135668-78) and Universidade Federal do ABC (ZUFABC 30-35).

\section{Tadpoles}

The larvae are staged according to Gosner (1960). We measured 28 tadpoles between Stages 26 and 42 with an ocular grid in a stereomicroscope to the nearest $0.01 \mathrm{~mm}$ (Table 1). Nomenclature and measurements follow those of Altig and McDiarmid (1999): total length (TL), body length (BL), tail muscle height (TMH), tail muscle width (TMW), dorsal (DFH) and ventral fin heights (VFH), body maximum width (BMW), body maximum height $(\mathrm{BMH})$, eye diameter (ED), frontonasal distance $(\mathrm{FN})$, nostril major axis $(\mathrm{N})$, and oral disc width (OD). 
In addition we measured internarial distance (IND), eye-nostril distance (END), and interorbital distance (IO) of Scrocchi and Lavilla (1986).

\section{Advertisement Call}

Advertisement calls were recorded with a Panasonic (RQ-L31) tape recorder and a directional microphone (Yoga HT81) in October $2005\left(6^{\circ} \mathrm{C}\right.$ air temperature; $N=17$ calls from a single male MZUSP 135674). We digitized the tape recordings at a sampling frequency of 44.1 $\mathrm{kHz}$ and 32 bits resolution with Adobe Audition 3.0. Fourteen of the 17 calls could be successfully isolated from the background noise caused by the high wind in Audacity ${ }^{\circledR}$ version 2.1.1 (Audacity 2016) by applying successive lowpass and high-pass filters based on each call oscillogram. We used the R package Seewave to analyze these isolated calls (Sueur et al. 2008), setting frame width with 1024 points and Hann window. Acoustic parameters include those proposed by Kohler and collaborators (2017) as guidelines to bioacustical descriptions focused on taxonomy-viz., call length, note length, number of notes per call, number of pulses per note, interval between notes, call rate, pulse rate, and call dominant frequency $(\mathrm{kHz})$. We used note-centered terminology (e.g., fig.7D, Kohler et al. 2017) and calculated temporal parameters by the interval between the $10 \%$ levels at the leading and trailing edges of the oscillogram.

\section{Results}

Cycloramphus bandeirensis was the only species in the genus that we found at the study area, and all frogs were encountered in high grasslands at elevations above $\sim 2,450 \mathrm{~m}$. Adults and juveniles were found from the end of October to December under small $(\sim 60 \mathrm{~cm}$ diameter $\times 20 \mathrm{~cm}$ high), scattered rocks; none was encountered in the stream. Individuals captured and handled were not aggressive.
We found the spawn in the same microhabitat (Figure 1B, C) under a small rock in the open field and not near a stream. The egg mass collected on 05 November 2005 contained about 130 eggs (egg diameter $6.3 \pm 0.68 \mathrm{~mm}$; yolk diameter $4.2 \pm 0.47 \mathrm{~mm} ; N=57$; ZUFABC 30 ). An adult was under the same rock, but it escaped before we could determine its sex. The first hatching in captivity occurred 11 days later (16 November 2005) in the eggs maintained in the dark at room temperature. Tadpoles from the eggs maintained in the refrigerator hatched within another 3 or 4 days. All tadpoles hatched at Stage 26 and did not feed for approximately 10 days while yolk was still visible in the gut.

Tadpoles were primarily active at night; they usually were attached to the underside of the rocks in the terrarium. They moved across the wet surfaces of the rocks by affixing their mouth to the rock and then pulling the body forward by abdominal muscular contraction. If disturbed, the tadpoles undulate the muscular tail rapidly resulting in a small jump across the surface. Some tadpoles fell in the water at the bottom of the terrarium, and although they were able to swim, they rapidly attempted to climb up a rock or the terrarium wall; if unsuccessful, they drowned. All tadpoles metamorphosed within 25 days.

Tadpole Description ( $N=28, Z U F A B C$ 31-35, Figure 2, Tables 1-2)

Body length less than one-third total length. Body depressed in lateral view, elliptical in dorsal view. Tadpoles in Stages 26-29 rounded and globular, both in dorsal and lateral aspects owing to the presence of yolk. Snout rounded. Nares small, dorsolateral, oval, without ornamentation, positioned closer to the snout than to the eyes. Interorbital distance approximately $25 \%$ greater than internarial distance. Eyes lateral and oriented dorsolaterally; eye diameter nearly $20 \%$ body length. Distinct meniscus in iris (Miranda-Ribeiro 1926, Barrasso et al. 2013) 
formed by a dorsal expansion that initially develops in Stage 33, reaching full development in Stage 35. A tiny sinistral spiracle aperture at the middle third of body visible in Stage 33 . Intestine reversal loop displaced to the left of the abdomen. Tail musculature width in dorsal view half body width, tapered toward a rounded tail tip. Dorsal and ventral fins low, ventral fin higher than the dorsal one. Ventral fin arising from body-tail junction in first stages of development, restricted in Stages 33-42 to distal third of tail. Skin flap covering venter of larva in Stages 3338 after yolk consumption; anterior margin posteriorly adjacent to oral disc with flap extending entire body and vent tube (Figure 1C). Posterior margin of flap shallowly bilobate. Lateral line system not visible. Oral disc anteroventral, two-thirds width of body. Marginal papillae unpigmented, cylindrical, longer than wide, distributed in a single row interrupted by a large anterior gap. Submarginal papillae absent. In tadpoles from Stages 26-29, oral disc with denticles and poorly keratinized jaw sheath. Labial tooth row formula (LTRF) at Stage 29: $2(2) / 2(1)$; variable from Stages 33$42: 2(2) / 3(1), 2(2) / 3(1,3)$, or $2(2) / 3(1,2,3)$. Rows $\mathrm{P}-1$ and $\mathrm{P}-2$ equal in length, and $\mathrm{P}-3$ two-thirds $\mathrm{P}-1$. Jaw sheath chisel-shaped with eight to ten short triangular serrations, six serrations per 0.25 linear millimeter.

When alive, tadpoles with white and reddish metallic hues owing to presence of iridophores and erythrophores (Figure 2B, C). Iridophores distributed along the body, but especially laterally. In preservative, body and tail coloration pale cream and ochre with melanophores evenly distributed dorsally, denser on lateral body, and forming serial bands in the tail. Venter pale white covered by translucent skin flap.

\section{Advertisement Call (N=14, Figure 3, Table 3)}

Male Cycloramphus bandeirensis call from beneath scattered small rocks in humid parts of the grasslands; they are not found in streams. Calls were heard by day and early at night, usually 

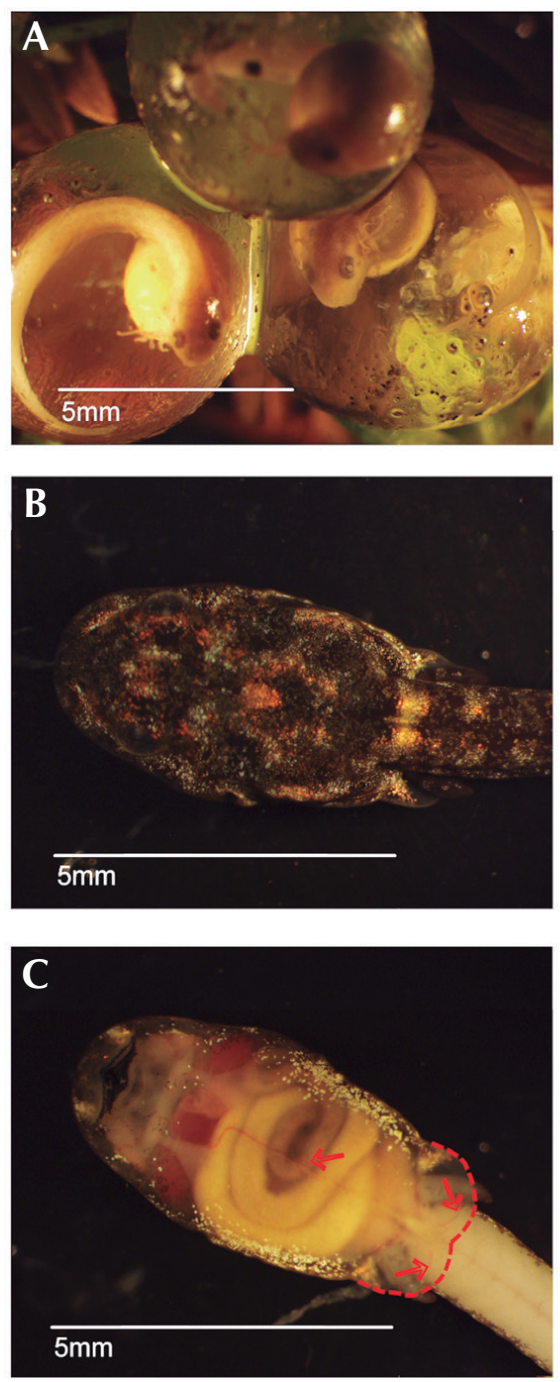
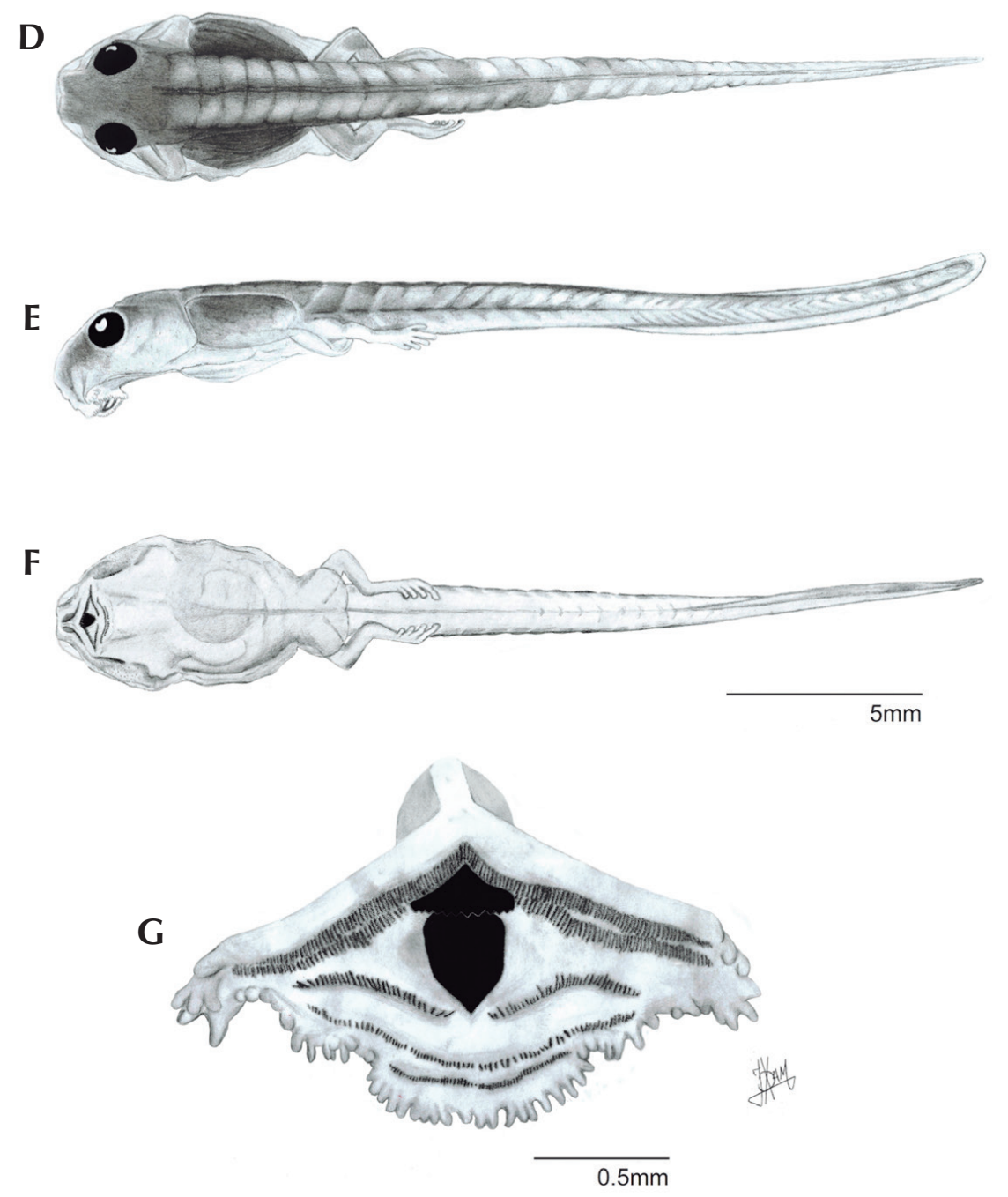

Figure 2. Photographs of (A) eggs of Cycloramphus bandeirensis and tadpole in (B) dorsal and (C) ventral view. Line drawings of the tadpole (ZUFABC 031, Stage 37): (D) dorsal, (E) lateral, and (F) ventral views; (G) oral apparatus. Dashed red line shows skin flap contour. Red arrows point to blood vessels irrigating the ventral flap.

in misty and rainy weather. Vocal activities intensify in the evening, but decrease and terminate when the temperature drops at night. In October 2006, we heard 20 males, spaced approximately $30 \mathrm{~m}$ from one another, calling simultaneously. The complex advertisement call consists of three or four notes (Figure 3A), with the first note differing from the following in length, amplitude modulation, and number of pulses (Figure 3B-E). The range of the first note length is $0.27-0.80 \mathrm{~s}(0.53 \pm 0.51 \mathrm{~s})$, whereas the lengths of the second, third, and fourth notes range from $0.08-0.24 \mathrm{~s}(0.13 \pm 0.03 \mathrm{~s})$. Calls with three or four notes are equally common $(N=7$, for both) lasting from 3.88-7.59 s $(5.85 \pm 1.07 \mathrm{~s})$. The call rate is 2.45 calls $/ \mathrm{min}$. The interval between the first and second note is $1.13-4.37 \mathrm{~s}$ $(2.36 \pm 0.83 \mathrm{~s})$, between the second and the third $1.28-2.36 \mathrm{~s}(1.84 \pm 0.34 \mathrm{~s})$, and between the third and fourth $1.20-1.75 \mathrm{~s}(1.47 \pm 0.22 \mathrm{~s})$. The first note has 9-25 distinguishable pulses (15.06 \pm $4.45)$, whereas the following notes range from 
A

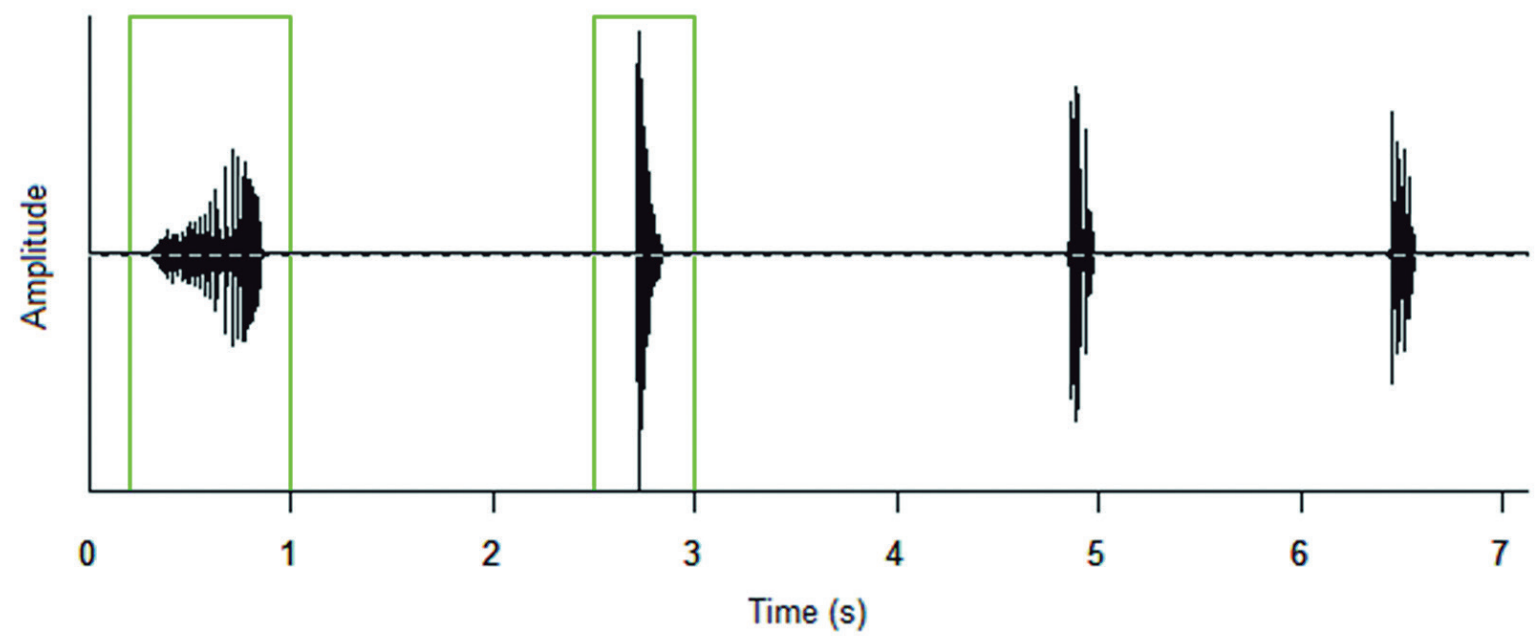

B

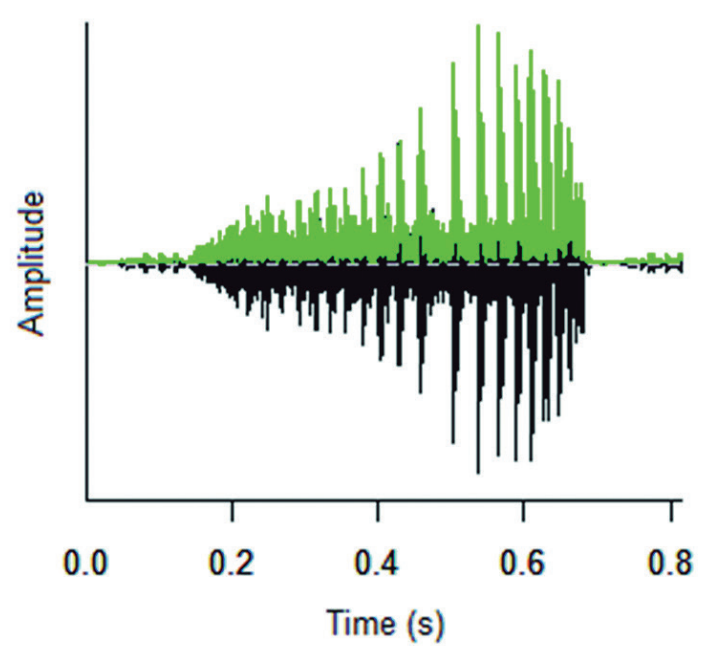

D

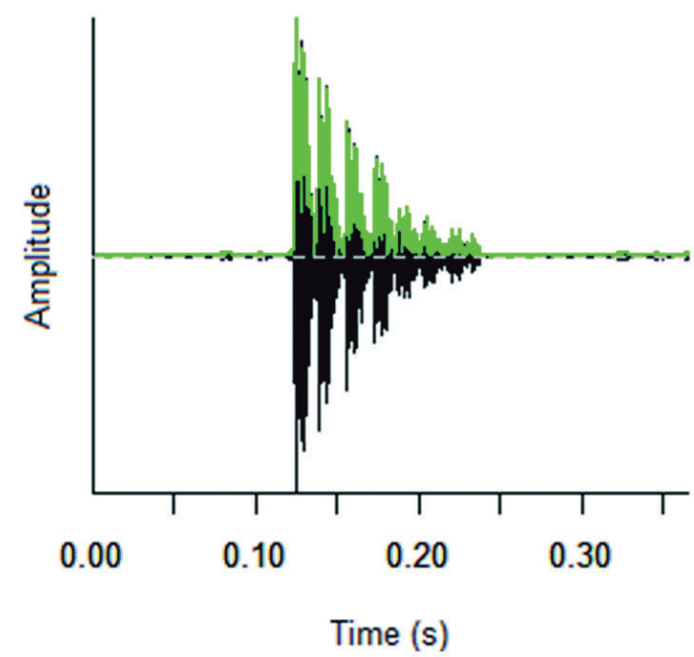

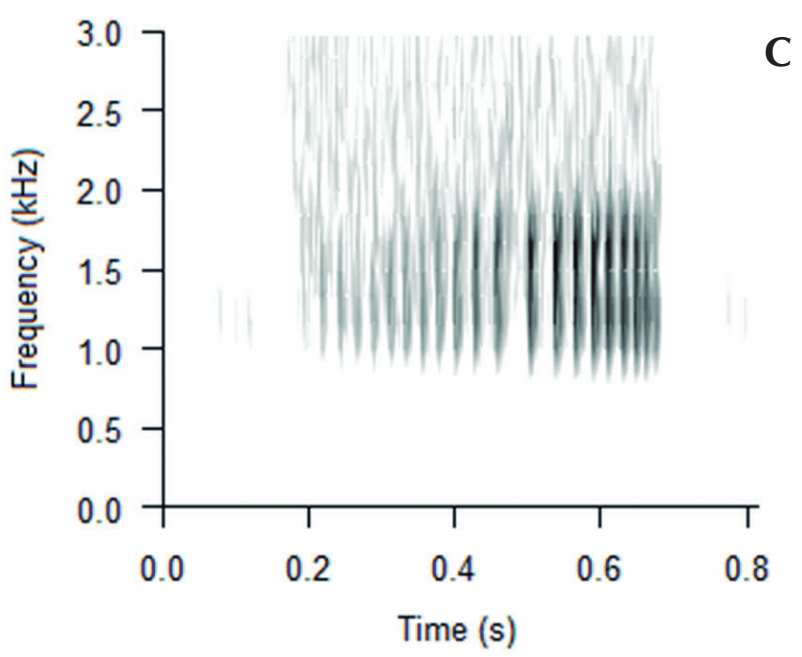

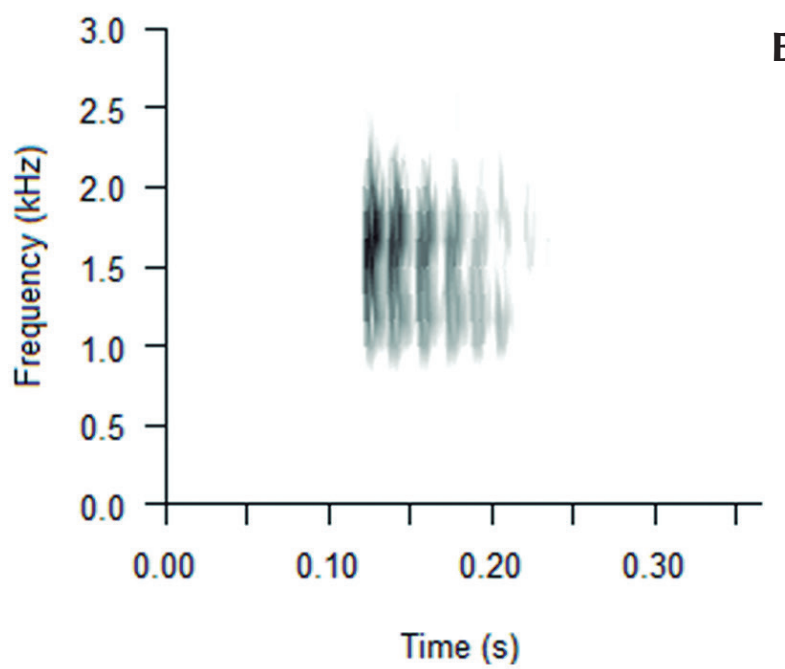

Figure 3. Advertisement call of Cycloramphus bandeirensis (MZUSP 135674, SVL $=40 \mathrm{~mm}$ ). (A) Oscillogram of the entire call, highlighting the first and second note types. (B, D). Oscillograms of first and second notes (sound envelope in green). (C, E) Spectrograms of first and second notes. Records: J. Cassimiro. 


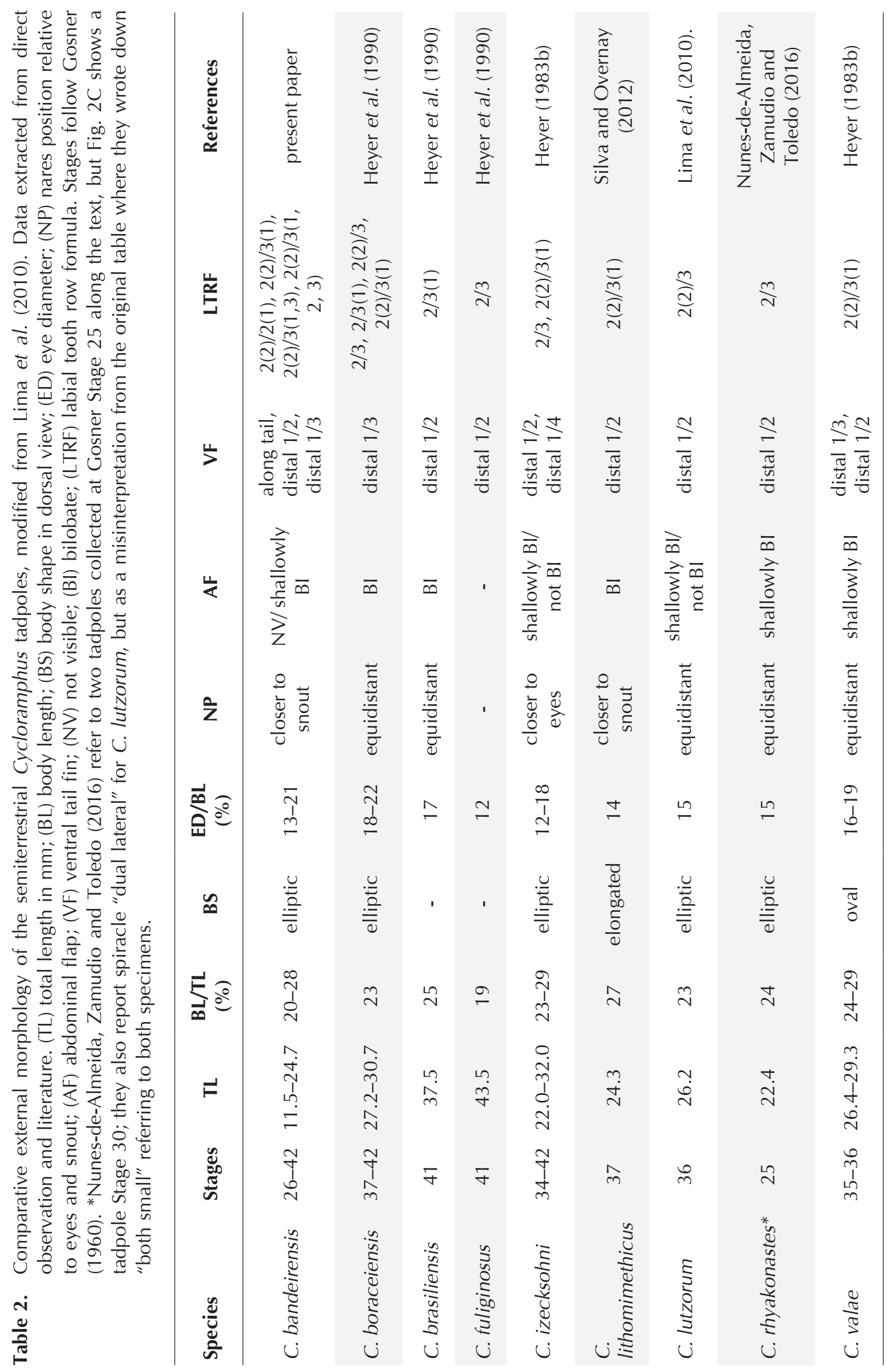


5-10 $(7.07 \pm 1.18)$ pulses (Figure 3B, D). The pulse rate in the first note is $29.82-55.56$ pulses/s $(42.9 \pm 5.94)$, and in the following ones, 25.00 90.00 pulses/s $(55.51 \pm 14.63)$. The dominant frequency of the advertisement call ranges from $1.03-1.98 \mathrm{kHz}(1.43 \pm 0.33 \mathrm{kHz})$. The dominant frequency of first note is $0.99-1.59 \mathrm{kHz}(1.14 \pm$ $0.14 \mathrm{kHz})$, of second note is $1.03-1.97 \mathrm{kHz}(1.5 \pm$ $0.32 \mathrm{kHz})$, of third note is $1.05-2.36 \mathrm{kHz}(1.50 \pm$ $0.40 \mathrm{kHz})$, and fourth note is $1.09-1.86 \mathrm{kHz}(1.39$ $\pm 0.28 \mathrm{kHz}$ ).

\section{Discussion}

We chose to undertake fieldwork in the open grasslands of Parque Nacional do Caparaó, based on the unpublished field notes of W. R. Heyer associated with the specimen of Cycloramphus bandeirensis in the collection. Heyer reported finding the single specimen collected in 1981 under a rock in the rocky fields. However, we expected to find the frogs under rocks near and along the stream running through the open grassland, given the semi-aquatic morphotype of C. bandeirensis (Heyer 1983a), which usually is associated with stream-dwelling species with semiterrestrial tadpoles. Contrary to our expectations, we only found the frogs and their eggs under the rocks in the rocky fields in the grasslands. All other semi-aquatic Cycloramphus are forest dwellers living in fast-flowing streams with exotrophic, semiterrestrial tadpoles associated with Reproductive Mode (RM) 19.

Haddad and Prado (2005) defined RM 19 as "Eggs on humid rocks, in rock crevices, or on tree roots above water; exotrophic semiterrestrial tadpoles living on rocks and rock crevices in a water film or in the water-land interface." The eggs of Cycloramphus bandeirensis are attached to wet rocks, but they are hidden beneath the rocks. This is a significant departure from the habits of most stream dweller cycloramphids which leave the eggs exposed and easily visible. A second difference involves the site of egg deposition with respect to water. The eggs of $C$. bandeirensis are terrestrial; they are neither associated with bodies of water nor wet vertical rocks. However, like RM-19 larvae, the tadpoles of $C$. bandeirensis crawl over wet rocks; thus, they meet the criterion of living in a "water film or in the water-land interface." Together, these features distinguish the reproductive mode of $C$. bandeirensis as a variant of RM 19-i.e., terrestrial eggs concealed under humid rocks in rocky fields, and exotrophic, semiterrestrial tadpoles living under wet rocks.

As in many frogs, especially those laying eggs in terrestrial environment, reproduction in Cycloramphus bandeirensis occurs during the rainy season from late October-December (Gomez-Mestre et al. 2012). Likewise, other cycloramphids with terrestrial eggs and tadpoles breed in the rainy season (Heyer and Crombie 1979, Mollo-Neto et al. 2016), and among the cycloramphids inhabiting forest streams and having semiterrestrial tadpoles, the breeding season also may be restricted to the rainy season (Giaretta and Facure 2004) or occur throughout the year (e.g., C. dubius; Giaretta and Cardoso 1995).

The spawn of Cycloramphus bandeirensis with 130 eggs is larger than that of its congeners: 30-40 eggs in $C$. faustoi and $C$. stejnegeri (Heyer and Crombie 1979, Brasileiro et al. 2007); 50 eggs in C. boraceiensis (Heyer et al. 1990); 70-80 in C. dubius (Giaretta and Cardoso 1995); and 80-100 in C. fuliginosus (Lutz 1929). In Thoropa miliaris (Spix 1824), there may be more than one spawning per breeding site (Giaretta and Facure 2004); this may be a possibility in $C$. bandeirensis. Males of streamdwelling Cycloramphus are territorial and actively defend their eggs by biting (Giaretta and Cardoso 1995, Giaretta and Facure 2003; Hartman et al. 2003). In the species that dwell in forest-litter, at least one adult stays with the egg clump (Heyer and Crombie 1979, Brasileiro et al. 2007). While we cannot state that parental care occurs in $C$. bandeirensis, the fact that an adult was found with the egg mass suggests that this may be the case.

At hatching, the tadpoles of Cycloramphus bandeirensis have the features associated with 
Table 3. Characteristics of advertisement calls for species of Cycloramphus with formally described calls. Modified from Lima et al. (2010) and including C. bandeirensis. The call type follows Heyer (1983a). *indicates we reclassified the call type based on its length.

\begin{tabular}{|c|c|c|c|c|c|}
\hline Species & Habitat & $\begin{array}{l}\text { Call } \\
\text { type }\end{array}$ & $\begin{array}{l}\text { Call length } \\
(\mathrm{s})\end{array}$ & $\begin{array}{c}\text { Dominant } \\
\text { frequency }(\mathrm{kHz})\end{array}$ & References \\
\hline C. bandeirensis & high grassland & $\mathrm{C}$ & $5.09-7.59$ & $1.03-1.97$ & present paper \\
\hline C. bolitoglossus. & litter & B & $3.95-4.48$ & $1.32-2.44$ & Lingnau et al 2008 \\
\hline C. boraceiensis & stream & A & $0.03-0.06$ & $0.50-3.50$ & $\begin{array}{l}\text { Heyer and Mello (1979), Heyer } \\
\text { (1983a), Heyer et al. (1990) }\end{array}$ \\
\hline C. brasiliensis & stream & C & 1.00 & $0.54-1.80$ & Heyer (1983a) \\
\hline C. dubius & stream & A & 0.20 & $1.20-3.10$ & Giaretta and Cardoso (1995) \\
\hline C. eleutherodactylus & forest floor & B & $4.04-4.34$ & $0.80-2.20$ & Brasileiro et al. (2007) \\
\hline C. faustoi & forest floor & B & $2.53-4.17$ & $0.90-2.20$ & Brasileiro et al. (2007) \\
\hline C. izecksohni & stream & A & $0.02-0.03$ & $1.30-2.7$ & Heyer (1983b) \\
\hline C. juimirim & stream & B & $0.40-0.70$ & $1.20-1.70$ & Haddad and Sazima (1989) \\
\hline C. lutzorum & stream & $A^{*}$ & $0.05-0.06$ & $0.98-1.39$ & Lima et al. (2010) \\
\hline C. ohausi & stream & B & $1.20-1.50$ & $0.80-1.00$ & Heyer (1983a) \\
\hline C. rhyakonastes & stream & A & $0.04-0.05$ & $1.0-2.5$ & Heyer (1983a) \\
\hline C. semipalmatus & stream & A & $0.02-0.04$ & $0.20-5.00$ & Heyer (1983a), Heyer et al. (1990) \\
\hline C. valae & dripping rock & $\mathrm{B}$ & $1.30-1.90$ & $1.25-2.25$ & Heyer (1983b) \\
\hline
\end{tabular}

semiterrestrial larvae-viz., the body shape, amount of yolk, presence of caudal fins, and conspicuously keratinized denticles and jaw sheath. Their nocturnal activity, apparent preference for attaching to the ceiling of the rocky refuges, and mode of locomotion are noteworthy. The tadpoles move on the rocks by affixing their mouth to the surface and contracting the abdomen to pull the body forward. When disturbed, they quickly undulate the muscular tail to propel the body forward. Veeranagoudar et al. (2009) described a similar, but more vigorous movement, as "flipping behavior" for the semiterrestrial tadpoles of Indirana beddomii
(Günther, 1876) (Ranixalidae). The tadpoles of Thoropa Cope, 1865 use similar movements to avoid predation by trap-jaw ants (genus Odontomachus) (Facure and Giaretta 2009).

Semiterrestrial tadpoles have an abdominal flap of skin that without suction, supposedly facilitates adherence to rocks (Wassersug and Heyer 1983, Altig and McDiarmid 1999). The tadpoles of Cycloramphus bandeirensis have the abdominal flap; however, we observed that in the presence of a film of running water, the water flows beneath the flap, moving the body of the tadpole. These observations are consistent with the shallow-water microhabitat preferences and 
behavior of the semiterrestrial tadpoles of Thoropa miliaris (Rocha et al. 2002). These observations, together with the elaboration of the abdominal blood vessels (Figure 3C) in the flap and the fact tadpoles drown if submerged, suggest that the flap may have an alternate function in larvae of $C$. bandeirensis.

Burggren and West (1982), studying bimodal gas exchange in tadpoles of Lithobates catesbeianus (Shaw, 1802), demonstrated that gas exchange through the skin contributes more to oxygen uptake than through the gills in aquatic tadpoles in initial stages, and that the contribution of the skin increases as that of the gills decreases during development. Semiterrestrial tadpoles of cycloramphids usually have relatively small branchial baskets and gill filters (Wassersug and Heyer 1983). Moreover, the larvae are not submerged such that they could maintain a high influx of water to branchial chambers; this may indicate that they rely more on cutaneous rather than gill respiration. We propose the abdominal flap of cycloramphid semiterrestrial tadpoles increases the surface area of the larvae, thereby accommodating cutaneous gas exchange.

Morphologically, the tadpoles of Cycloramphus bandeirensis resemble other semiterrestrial cycloramphid larvae. The positions of eyes and nares, snout shape, LTRF, shape of the skin flap edge, and the extension of caudal fins (Table 2) characterize larvae in the semiterrestrial guild. The LTRFs vary during development, mainly with respect to the presence of gaps in the posterior rows of denticles. The presence and development of the iris meniscus, the skin flap, spiracle, and reduced caudal fin are most obvious in tadpoles of Stages 33-38. Unfortunately, there is little information on the ontogeny and phenotypic variation in descriptions of tadpoles of Cycloramphus (e.g., Lima et al. 2010, Nunesde-Almeida et al. 2016).

Aside from the ontogenetic variation described above, we noted that the development of the oral disc and limbs in tadpoles of Cycloramphus bandeirensis are not consistent with the descriptions of Gosner (1960) stages for generalized tadpoles. Cycloramphus bandeirensis tadpoles hatched with internal gills and small limb buds (Stage 26), but the oral disc is not fully developed until Stage 27 (oral disc fully developed in Stage 25). Similarly, when the forelimbs emerged (Stage 42), parts of the oral disc were keratinized (Stage 39 of Gosner). Variations in developmental rates of fore- and hind limbs in stream tadpoles were reported for Arthroleptides martiensseni Nieden, 1911 "1910" (Petropedetidae) (Drewes et al. 1989) and Indirana beddomii (Ranixalidae) (Veeranagoudar et al. 2009). Similarly, a delay in the development of oral apparatus was reported for the endotrophic terrestrial tadpoles of Eupsophus emiliopugini Formas, 1989 (Alsodidae) relative to that of exotrophic species (Formas 1989, Candioti et al. 2011). These apparent heterochronic shifts in development of different types of frog larvae require further investigation.

Comparative analyses of the advertisement calls in Cycloramphus are hampered by two different kinds of descriptions-i.e., callcentered descriptions versus note-centered. There are short simple calls, long simple calls, and complex calls, that approximately correspond to Types A, B, and C proposed by Heyer (1983a). Only Cycloramphus bandeirensis and $C$. brasiliensis (Steindachner 1864) are known to have a complex advertisement call (Type C, Heyer 1983a), which includes characteristics of Type-A (one or two short metallic notes) and Type-B (one long note) calls of Heyer (1983a). The advertisement calls of seven species of Cycloramphus were described after 1983; those of C. bolitoglossus (Lingnau et al. 2008), $C$. eleutherodactylus, C. faustoi (Brasileiro et al. 2007), C. juimirim (Haddad and Sazima 1989), and C. valae (Heyer 1983b) are long, Type-B calls. Although the advertisement call of $C$. lutzorum was described as Type B (Lima et al. 2010), it actually is Type A; the authors used a scale of milliseconds, giving the impression of a long note, but the note length is $0.05-0.06 \mathrm{~s}$, as observed in $C$. boraceiensis, for example (Table 
$3)$. There is no clear association of types of advertisement calls with taxonomy, habitat, or phenotypic characters; thus far, stream-dwelling species of Cycloramphus have simple long, short, or complex calls, whereas all the forestlitter Cycloramphus have long simple calls.

Without a robust phylogenetic framework, we cannot discuss evolution of ecomorphotypes, reproductive specialization, or the association of call types with different clades. Cycloramphidae includes species with RMs 19, 21, 22, and a variant to RM 19, two larval morphotypes, and three types of advertisement calls. From the unpublished academic works available, RMs 21 and 22 would have risen once in the group from an ancestor with RM 19 (Verdade 2005, Barros 2016). Alternately, the molecular data points to multiple origin of terrestrial reproduction (RMs 21 and 22) (de Sá et al. 2019).

\section{Conservation Status}

Cycloramphus bandeirensis is classified as Data Deficient by the IUCN (Silvano and Heyer 2004). Our data and those from later expeditions (Zornosa-Torres et al., 2019) indicate the species is endemic to the open rocky fields of the high grasslands of Parque Nacional do Caparaó. The total area of the high grassland of the park (2000-2890 m a.s.1.) is $78.7 \mathrm{~km}^{2}$ (yellow line, Figure 1A). However, we only found specimens above $2450 \mathrm{~m}$; therefore, the extent of occurrence of the species would be $9.3 \mathrm{~km}^{2}$ (red line, Figure 1A). According to the IUCN website, the species only occurs between elevations of 2450 and $2740 \mathrm{~m}$ (Silvano and Heyer 2004), which is consistent with our findings. However, the polygon on the map does not match altitudinal isoclines; thus, it includes areas of forest below $2000 \mathrm{~m}$ with areas of high grassland (green line, Figure 1A).

The national park is protected area but includes camping facilities at altitudes of $\sim 2370 \mathrm{~m}$ in "Terreirão," and $2200 \mathrm{~m}$ in "Casa Queimada." Excursions to Bandeira Peak are common, but seemingly do not threaten the frogs. Although
Cycloramphus bandeirensis occurs within a preserve, the species has stringent environmental requirements involving high and continuous levels of humidity for reproduction associated with its preferred microhabitat isolated on a mountaintop. It is a vulnerable species under the rarity indicator proposed by Toledo et al. (2014). The species also is related to cycloramphids that have undergone local population crashes in southeastern Brazil [e.g., Thoropa lutzi Cochran, 1938, T. petropolitana (Wandolleck ,1907), Cycloramphus boraceiensis, C. dubius, and C. semipalmatus (Miranda-Ribeiro, 1920)]; see Verdade et al. (2011) for a summary on the decline of amphibians in Brazil. Cycloramphid frogs are considered evolutionarily distinct with a low diversification rate, and thus, more susceptible to human-driven environmental changes (Greenberg et al. 2018).

From the usual potential factors leading frogs to population crashes worldwide, the climate change is a plausible threat to Atlantic Forest frogs, especially for those restricted to small mountaintops. It is predicted that Cycloramphus juimirim, C. lutzorum, and C. semipalmatus will lack climatically suitable habitats by $2050 / 2070$ (Vasconcelos et al. 2018). Although there are no specific projections as to the effects of climate change on the Brazilian high grassland ecosystems and their species, projections for other high-altitude ecosystems in Latin America include habitat reduction, species shift distribution, population declines, modifications in phenology, and increase in species invasions. [See Scarano et al. (2016) for summary of the plight of Brazilian high grasslands.] Additionally, fires are also plausible potential threats in high grasslands (Garey and Provete 2016). The species within the park seem free from chytrid fungus (Batrachochytrium dendrobatidis; $B d$ ) (Rodriguez et al. 2014), but the $B d$ cannot be ruled out as a potential threat (Garey and Provete 2016).

The information provided herein justifies withdrawal of Cycloramphus bandeirensis from the IUCN DD category, which is intended for species lacking adequate information to allow 
direct or indirect assessment of risk of extinction based on distribution or population status (IUCN 2018). We propose the transfer Cycloramphus bandeirensis to the Vulnerable category (VU, d2) of IUCN, based on the restricted distribution and plausible threats (e.g., fires, and climatic global change) to the species that might lead to population declines in less than a century.

\section{Acknowledgments}

We thank Ibama/ICMBio for collection permits (030/2005-CGFAU/LIC); FAPESP for financial support (processes 2001/054708,2003/10335-8, 2003/10335-8 and 2011/501466 ); and H. Zaher from MZUSP for loan of specimens. We are profoundly grateful to E. J. $\mathrm{M}$. Fonseca, the former director of PNC, for enthusiastically providing lodging and facilities during our stays. We also thank our helpful and good-humored field guide Paraíba, and our colleagues who participated in the fieldwork during the many expeditions made to the Serra do Caparaó: D. Pavan, F. F. Curcio, L. D. Matos, M. Teixeira Jr., and R. S. Recoder. We are also grateful for the suggestions of the editor and anonymous reviewers, and the English review of L. Trueb that greatly improved the manuscript.

\section{References}

Almeida-Silva, D., V. C. O. Rocha-Barros, R. B. Ferreira, and V. K. Verdade. 2019. The tadpole of Zachaenus carvalhoi Izecksohn, 1983 (Anura: Cycloramphidae). Zootaxa 4668: 145-147

Altig, R. and R. W. McDiarmid. 1999. Body plan development and morphology. Pp. 24-51 in R. W. McDiarmid and R. Altig (eds.), Tadpoles. The biology of anuran larvae. Chicago and London. University of Chicago Press.

Audacity. 2016. Audacity®: Free Audio Editor and Recorder (Computer program). Version 2.1.1 retrieved 20 November 2016 from http://www.audacityteam.org/ download/.
Barraso, D. A., L. Cotichelli, L. Alcalde, and N. Basso. 2013. Re-description of the tadpole of Pleurodema somuncurensis (Cei, 1969) (Amphibia: Anura). Zootaxa 3681: 192-196.

Barros, V. C. O. R. 2016. Sobre o posicionamento filogenético de Cycloramphus Tschudi 1838 e Zachaenus Cope 1866 (Anura: Cycloramphidae) à luz da morfologia larval. Unpublished M.Sc. Dissertation. Universidade Federal do ABC. Brazil.

Bokermann, W. C. A. 1965. Notas sobre as espécies de Thoropa Fitzinger (Amphibia, Leptodactylidae). Anais da Academia Brasileira de Ciências 37: 524-537.

Brasileiro, C. A., C. F. B. Haddad, R. J. Sawaya, and I. Sazima. 2007. A new and threatened island-dwelling species of Cycloramphus (Anura: Cycloramphidae) from Southeastern Brazil. Herpetologica 63: 501-510.

Burgrren, W. W. and N. H. West. 1982. Changing respiratory importance of gills, lungs and skin during metamorphosis in the bullfrog Rana catesbeiana. Respiration Physiology 47: $151-164$.

Candioti, M. F. V., J. J. Nuñez, and C. Úbeda. 2011. Development of the nidicolous tadpoles of Eupsophus emiliopugini (Anura: Cycloramphidae) until metamorphosis, with comments on systematic relationships of the species and its endotrophic developmental mode. Acta Zoologica 92: 27-45.

de Sá, F. P., C. F. B. Haddad, M. M. Gray, V. K. Verdade, M. T. C. Thomé, M. T. Rodrigues, and K. R. Zamudio. 2019. Male-male competition and repeated evolution of terrestrial breeding in Atlantic Coastal Forest frogs. Evolution: doi:10.1111/evo.13879.

Drewes, R. C., R. Altig, and K. M. Howell. 1989. Tadpoles of three frog species endemic to the forests of the Eastern Arc Mountains, Tanzania. Amphibia-Reptilia 10: $435-443$.

Facure, K. G. and A. A. Giaretta. 2009. Semi-terrestrial tadpoles as a vertebrate prey of trap-jaw ants (Odontomachus, Formicidae). Herpetology Notes 2: 63-66.

Formas, J. R. 1989. A new species of Eupsophus (Amphibia: Anura: Leptodactylidae) from southern Chile. Proceedings of Biological Society of Washington 102: $568-576$.

Fouquet, A., B. L. Blotto, M. M. Maronna, V. K. Verdade, F. A. Juncá, R. O. de Sá, and M. T. Rodrigues. 2013. Unexpected phylogenetic positions of the genera Rupirana and Crossodactylodes reveal insights into the biogeography and reproductive evolution of leptodactylid frogs. Molecular Phylogenetic Evolution 67: 445-457. 
Frost, D. R. (ed.) 2019. Amphibian Species of the World: an Online Reference. Version 6.0. Electronic Database accessible at http://research.amnh.org/herpetology/ amphibia/index.html. American Museum of Natural History, New York, USA. Captured on 10 March 2019.

Frost, D. R., T. Grant, J. Faivovich, R. H. Bain, A. Haas, C. F. B. Haddad, R. O. Sá, A. Channing, M. Wilkinson, S. C. Donnellan, C. J. Raxworthy, J. A. Campbell, B. L. Blotto, P. Moler, R. C. Drewes, R. A. Nussbaum, J. D. Lynch, D. M. Green, and W. C. Wheeler. 2006. The amphibian tree of life. Bulletin of American Museum Natural History 297: 1-370.

Garey, M. V. and D. B. Provete. 2016. Species composition, conservation status, and sources of threat of anurans in mosaics of highland grasslands of southern and southeastern Brazil. Oecologia Australis 20: 94-108.

GBBPEA (ed.). 2013. Guia Brasileiro das Boas Práticas de Eutanásia Animal, Conceitos e Procedimentos Recomendados. Brasília. Conselho Federal de Medicina Veterinária. XX pp.

Giaretta, A. A. and A. J. Cardoso. 1995. Reproductive behavior of Cycloramphus dubius Miranda-Ribeiro (Amphibia, Anura, Leptodactylidae). Revista Brasileira de Zoologia 12: 233-237.

Giaretta, A. A. and K. G. Facure. 2003. Cycloramphus boraceiensis (Flattened Waterfall Frog). Clutch attendance. Herpetological Review 34: 50.

Giaretta, A. A. and K. G. Facure. 2004. Reproductive ecology and behavior of Thoropa miliaris (Spix, 1824) (Anura, Leptodactylidae, Telmatobiinae). Biota Neotropica 4: 1-10.

Gomez-Mestre, I., R. A. Pyron, and J. J. Wiens. 2012. Phylogenetic analyses reveal unexpected patterns in the evolution of reproductive modes in frogs. Evolution 66: $3687-3700$.

Gosner, K. L. 1960. A simplified table for staging anuran embryos and larvae with notes on identification. Herpetologica 16: 183-190.

Grant T., M. Rada, M. Anganoy-Criollo, A. Batista, P. H. Dias, A. M. Jeckel, D. J. Machado, and J. V. RiedaAlmonacid. 2017. Phylogenetic systematics of dart poison frogs and their relatives revisited (Anura: Dendrobatoidea). South American Journal of Herpetology 12: 1-90.

Greenberg, D. A., W. J. Palen, K. C. Chan, W. Jetz, and A. O. Mooers. 2018. Evolutionarily distinct amphibians are disproportionately lost from human-modified ecosystems. Ecology Letters 21: 1-11.
Haddad, C. F. B. and C. P. A. Prado. 2005. Reproductive modes in frogs and their unexpected diversity in the Atlantic Forest of Brazil. BioScience 55: 207-217.

Haddad, C. F. B. and I. Sazima. 1989. A new species of Cycloramphus from southeastern Brazil (Amphibia: Leptodactylidae). Herpetologica 45: 425-429.

Hartman, M. T., P. A. Hartman, C. P. A. Prado, and P. C. A. Garcia. 2003. Cycloramphus boraceiensis (Flattened Waterfall Frog). Defensive behavior. Herpetology Review 34: 50.

Heyer, W. R. 1983a. Variation and systematics of frogs of the genus Cycloramphus (Amphibia, Leptodactylidae). Arquivos de Zoologia, São Paulo 30: 235-339.

Heyer, W. R. 1983b. Notes on the frog genus Cycloramphus (Amphibia: Leptodactylidae), with descriptions of two new species. Proceedings of Biological Society of Washington 96: 548-559.

Heyer, W. R. and R. I. Crombie. 1979. Natural history notes on Craspedoglossa stejnegeri and Thoropa petropolitana (Amphibia: Salientia, Leptodactylidae). Journal of Washington Academy of Science 69: 17-20.

Heyer, W. R. and L. R. Maxson. 1983. Relationships, zoogeography, and speciation mechanisms of frogs of the genus Cycloramphus (Amphibia, Leptodactylidae). Arquivos de Zoologia, São Paulo 30: 341-373.

Heyer, W. R. and C. C. Mello. 1979. Descriptions of the advertisement calls of Cycloramphus asper and Cycloramphus dubius (Amphibia: Leptodactylidae). Papéis Avulsos de Zoologia, São Paulo 32: 193-200.

Heyer, W. R., A. S. Rand, C. A. G. Cruz, O. L. Peixoto, and C. E. Nelson. 1990. Frogs of Boracéia. Arquivos de Zoologia, São Paulo 31: 231-410.

Iskandar, D. T., B. J. Evans, and J. A. McGuire. 2014. A novel reproductive mode in frogs: a new species of fanged frog with internal fertilization and birth of tadpoles. PLOS ONE 9: 1-14.

IUCN. 2018. The IUCN Red List of Threatened Species. Version 2018-2. Electronic Database accessible at http:// www.iucnredlist.org. Captured on 22 February 2019.

Jetz W. and R. A. Pyron. 2018. The interplay of past diversification and evolutionary isolation with present imperilment across the amphibian tree of life. Nature Ecology and Evolution: doi:10.1038/s41559-018-0515-5.

Kohler, J., M. Jansen, A. Rodríguez, P. J. R. Kok, L. F. Toledo, M. Emmrich, F. Glaw, C. F. B. Haddad, M.-O. Rödel, and M. Vences. 2017. The use of bioacoustics in anuran taxonomy: theory, terminology, methods and recommendations for best practice. Zootaxa 4251: $1-124$. 
Lima, A. M. X., C. O. Araujo, and V. K. Verdade. 2012. Cycloramphus eleutherodactylus (alto button frog): calling among rocks and caves. Herpetological Bulletin 120: $39-42$.

Lima, A. M. X., M. V. Garey, R. B. Noleto, and V. K. Verdade. 2010. Natural history of the Lutz's Frog Cycloramphus lutzorum Heyer, 1983 (Anura: Cycloramphidae) in the Brazilian Atlantic Forest: description of the advertisement call, tadpole, and karyotype. Journal of Herpetology 44: 360-371.

Lingnau, R., M. Solé, F. Dallacorte, and A. Kwet. 2008. Description of the advertisement call of Cycloramphus bolitoglossus (Werner, 1897), with comments on other species in the genus from Santa Catarina, south Brazil (Amphibia, Cycloramphidae). North-Western Journal of Zoology 4: 224-235.

Lutz, A. 1929. Taxonomia e biologia do gênero Cyclorhamphus. Memórias do Instituto Oswaldo Cruz. 21: $5-21$.

Lutz, B. 1944. Biologia e taxonomia de Zachaenus parvulus. Boletim do Museu Nacional Zoologia, Nova Série, Zoologia 17: 1-65.

Miranda-Ribeiro, A. 1926. Notas para servirem ao estudo dos Gymnobatrachos (Anura) brasileiros. Arquivos do Museu Nacional, Rio de Janeiro 27: 1-227.

Mollo-Neto, A., V. K. Verdade, D. J. Santana, C. H. V. Rios, R. M. H. Carvalho, and M. T. Rodrigues. 2016. Reproductive biology and geographic variation of Zachaenus carvalhoi (Anura: Cycloramphidae), a Brazilian Atlantic Forest frog. Phyllomedusa 15: 127135.

Nunes-de-Almeida, C. H. L., K. R. Zamudio, and L. F. Toledo. 2016. The semiterrestrial tadpole of Cycloramphus rhyakonastes Heyer, 1983 (Anura, Cycloramphidae). Journal of Herpetology 50: 289-294.

QGIS. 2019. QGIS Geographic Information System. Open Source Geospatial Foundation Project. Eletronic Database accessible at http://www.qgis.org/. Captured on 20 February 2019.

Rocha, C. F. D., M. van Sluys, H. G. Bergallo, and M. A. S. Alves. 2002. Microhabitat use and orientation to water flow direction by tadpoles of the leptodactylid frog Thoropa miliaris in southeastern Brazil. Journal of Herpetology 36: 98-100.

Rodrigues, M. T., J. Cassimiro, D. Pavan, F. F. Curcio, V. K. Verdade, and K. C. M. Pellegrino. 2009. A new genus of microteiid lizard from the Caparaó mountains, Southeastern Brazil, with a discussion of relationships among Gymnophthalminae (Squamata). American Museum Novitates 3673: 1-27.
Rodriguez, D., C. G. Becker, N. C. Pupin, C. F. B. Haddad, and K. R. Zamudio. 2014. Long-term endemism of two highly divergent lineages of the amphibian-killing fungus in the Atlantic Forest of Brazil. Molecular Ecology 23: 774-787.

Sabbag, A. F., M. L. Lyra, K. R. Zamudio, C. F. B. Haddad, R. N. Feio, F. S. F. Leite, J. L. Gasparini, and C. A. Brasileiro. 2018. Molecular phylogeny of Neotropical rock frogs reveals a long history of vicariant diversification in the Atlantic forest. Molecular Phylogenetic Evolution 122: 142-156.

Scarano, F. R., P. Ceotto, and G. Martinelli. 2016. Climate change and "campos de altitude": forecasts, knowledge and action gaps in Brazil. Oecologia Australis 20: 1-6.

Scrocchi, G. J. and E. O. Lavilla. 1986. Caracteres para la identificacion de las especies cripticas Leptodactylus gracilis y L. geminus (Anura: Leptodactylidae). Physis, Secc.C 44: 93-95.

Silvano, D. and R. Heyer. 2004. Cycloramphus bandeirensis. 2018 IUCN Red List of Threatened Species. Eletronic Database accessible at https://www.iucnredlist.org/ species/56358/11452655. Captured on 03 March 2019.

Streicher, J. W., E. C. Millera, P. C. Guerrero, C. Correa, J. C. Ortiz, A. J. Crawford, M. R. Pie, and J. J. Wiens. 2018. Evaluating methods for phylogenomic analyses, and a new phylogeny for a major frog clade (Hyloidea) based on 2214 loci. Molecular Phylogenetic Evolution 119: 128-143.

Sueur, J., T. Aubin, and C. Simons. 2008. Equipment review. Seewave, a free modular tool for sound analysis and synthesis. Bioacoustics 18: 213-226.

Toledo, L. F., C. G. Becker, C. F. B. Haddad, and K. R. Zamudio. 2014. Rarity as an indicator of endangerment in neotropical frogs. Biological Conservation 179: 5462.

Vasconcelos, T. S., B. T. M. Nascimento, and V. H. Prado. 2018. Expected impacts of climate change threaten the anuran diversity in the Brazilian hotspots. Ecology and Evolution 00: 1-13.

Veeranagoudar, D. K., R. S. Radder, B. A. Shanbhag, and S. K. Saidapur. 2009. Jumping behavior of semiterrestrial tadpoles of Indirana beddomii (Günth.): relative importance of tail and body size. Journal of Herpetology 43: $680-684$.

Verdade, V. K. 2005. Relações filogenéticas entre as espécies dos gêneros Cycloramphus Tschudi, 1838 e Zachaenus Cope, 1866 (Anura, Leptodactylidae). Unpublished PhD Thesis. Universidade de São Paulo, Brazil. 
Verdade, V. K. and M. T. Rodrigues. 2003. Description of a new species of Cycloramphus (Anura: Leptodactylidae) from Atlantic Forest, Brazil. Herpetologica 59: 513518.

Verdade, V. K., J. Cassimiro, and M. T. Rodrigues. 2009a. Amphibia, Anura, Cycloramphidae, Zachaenus carvalhoi Izecksohn, 1983 and Z. parvulus (Girard, 1853): Filling gap and geographic distribution map for the genus. Check List 5: 55-758.

Verdade, V. K., J. Cassimiro, and M. T. Rodrigues. 2009b. Natural history notes. Cycloramphus fuliginosus (Tschudi's Button Frog). Saurophagy. Herpetological Review 40: 201-202.

Verdade, V. K., A. C. Carnaval, M. T. Rodrigues, L. Schiesari, D. Pavan, and J. Bertoluci. 2011. Decline of Amphibians in Brazil, Chapter 5. Pp. 85-127 in $\mathrm{H}$. Heatwole (ed.), Amphibian Biology. Volume 9. Co-edit by C. I. Barrio-Amorós and J. W. Wilkinson, Status of Decline of Amphibians: Western Hemisphere. Part 2: Uruguay, Brazil, Ecuador, and Colombia. Baulkham Hills. Surrey Beatty and Sons.

Wassersug, R. and W. R. Heyer. 1983. Morphological correlates of subaerial existence in leptodactylid tadpoles associated with flowing water. Canadian Journal of Zoology 61: 761-769.

Weber, L. N., V. K. Verdade, R. O. L. Salles, A. Fouquet, and S. P. Carvalho e Silva. 2011. A new species of Cycloramphus Tschudi (Anura: Cycloramphidae) from the Parque Nacional da Serra dos Órgãos, Southeastern Brazil. Zootaxa 2737: 19-33.

Wells, K. D. 2007. The Ecology and Behavior of Amphibians. Chicago and London. The University of Chicago Press. $1148 \mathrm{pp}$.

Zocca, C. Z., F. C. L. Ferreira, and R. B. Ferreira. 2014. Observações sobre história natural de Zachaenus carvalhoi Izecksohn, 1983 "1982" (Amphibia: Anura: Cycloramphidae). Boletim do Museu de Biologia Mello Leitão, Nova Série 34: 63-74.

Zornosa-Torres, C, G. Augusto-Alves, M. L. Lyra, J. C. Silva Jr., P. C. A. Garcia, F. Leite, V. K. Verdade, M. T. Rodrigues, J. L. Gasparini, C. F. B. Haddad, L. F. Toledo. 2019. Anuros do Parque Nacional do Caparaó e arredores. IX Congresso Brasileiro de Herpetologia, Campinas, Brazil.

Editor: Ariovaldo A. Giaretta 